\title{
Regulatory Framework and the Nigeria Tourism Economy
}

\author{
Yekinni Ojo BELLO, $\mathrm{PhD}^{1}$, Mercy Busayo BELLO ${ }^{2}$ \\ ${ }^{1}$ University of Port Harcourt, Faculty of Management Sciences, Department of Hospitality Management and Tourism \\ Choba, Rivers State, Nigeria \\ ${ }^{2}$ Federal Polytechnic Auchi, School of Applied Sciences, Department of Hospitality Management Auchi, Edo State, Nigeria.
}

\begin{abstract}
Purpose- This paper examines the extent feasible tourism regulatory framework can contribute to unlocking Nigeria tourism economy.

Research Methodology- The study been an exploratory study, reviewed various reports and previous literature in this domain of study upon which insightful inferences were made.
\end{abstract}

Findings- The study finds that Nigeria can only maximise her tourism economy potentials if tourism regulatory framework gear towards environmental sustainability, a secure and safe Nigeria, prioritisation of the tourism sector, and promotion of health and sanitary practices are galvanized.

Research Implications- By establishing five major areas of tourism regulatory framework, the study offers an insight on the need for the government of Nigeria to vigorously purse effort to sustaining her environment for accelerated tourism business development, taking decisive action to overhauling her security architecture, urgently restore tourism to a full ministry status as against the current merger of the sector including, a bold step to appoint experts as minister of tourism. Others include, announcement in clear terms the plan by the country to become open defecation free country by year 2025.

Originality: This study is the first to establish the connection between regulatory framework and the Nigeria tourism economy. The study argues that feasible tourism regulatory framework has the capacity to remodeling the Nigeria choking tourism economy.

Keywords:Tourism Economy, Regulatory Framework, Oil Economy, Nigeria.

\section{INTRODUCTION}

A Regulatory framework is essential for effective management, operation and maintenance of sustainable tourism economy of countries. The fortune of tourism economy in any socio-economic setting, like other sectors of the economy, is shaped by well-designed regulatory framework. This implies that the legal and regulatory regime have the most far-reaching positive impact on tourism economy performance of countries. There is no doubt that Nigeria ranks among the most privileged nations of the world in terms of endowment of tourism resources (Okoli, 2001; Bello \& Bello, 2017). Despite the huge tourism resources in Nigeria, the tourism economy performance of the country is undesirable. An analysis of available recent statistics shows that the Nigeria tourism economy is not performing competitively compared to other countries in Africa (Bello, 2018). It was reported that Sub-Saharan Africa attracted 36 million out of 54 million $(67 \%)$ international tourists that visited Africa in 2017 and earned USD\$ 25 million put at 74\% of the total tourist receipts in Africa (UNWTO, 2018). This seems to be an attractive performance compared to African region performance generally. However, tourist arrival in Nigeria in the year under review is below expectation as report has it that Nigeria is lagging far behind South Africa that attracted 8,904 million international tourists, Zimbabwe (2,057 million), Mozambique (1,552 million), Mauritania (1,152 million), Kenya (1,114 million), and Cape Verde (520 Million) (UNWTO, 2018). In terms of international tourist receipts, Nigeria earned USD\$ 404 million put at $1.2 \%$ of the entire international tourist receipts accrued to Sub-Sahara Africa (UNWTO, 2018). The index in the above information shows a poor performance of the Nigeria tourism economy.

It is pertinent to state that many factors may be responsible for this poor performance of the Nigeria tourism economy. Major among this factor is absence of feasible tourism regulatory framework. A well-designed tourism regulatory framework gives clear guidelines on sustainable tourism economy development.

The problems essentially that calls for this study is that limited study had examined elements of regulatory framework capable of maximizing sustainable tourism economy in Nigeria. Hence, the current study aims to explore and propose feasible regulatory framework for sustainable development of tourism economy in Nigeria. The outcome of this study is expected to contribute to literature practicable regulatory framework for workable tourism economy development in emerging country like Nigeria.

\section{LITERATURE REVIEW}

\section{Definition of Regulatory Framework}

Regulatory framework is defined as those elements that are policy related and generally under the purview of the government (Okoli, 2001). It is a series of steps taken by the government to develop responsive actions. It explains various laws, regulations, decrees and policies officially developed and approved by the government, for the purposes of regulation. Regulatory framework is accountability mechanism: a method by which the regulator accounts for the 
responsibilities conferred upon it. It also means the regulations, decisions, directives, regulatory policies, guidelines, recommendations and procedures made by the authorities from time to time including, any revisions or amendments made to it. The index in the above definitions show that regulatory framework implies legal and constitutional provisions that are essential for effective development of sustainable tourism economy.

\section{The Concept of Tourism Economy}

There is no stereotyped definition for the concept tourism economy. Various definitions had been offered based on the understanding of the definers. The concept explains all businesses that cater for the needs of the travelling public (Wall \& Mathieson, 2006; Robert et al. 2010). Tourism economy is seen as economy type that support businesses that focused on the provision of tourists' products and services capable of enhancing the touristic experience of tourists while contributing towards the economic development of the host communities (Naido, 2007). Tourism economy is defined as those internationally impactful economy with wide cross section components of products such as religion (Bello \& Bello, 2017; Bello \&Majebi, 2018), sport (Bello et al. 2017), accommodation (Bello \& Bello 2015; Bello \&Majebi, 2018), recreation (Bello \& Bello, 2017), food and other related services (Anthony et al. 2004; Jennifer \& Thea, 2013; UNWTO, 2016). It was reported that tourism economy provides both direct expenditures to the host region and the indirect effect of these expenditures on the destination income when an appropriate spending multiplier is applied (Bello \& Bello, 2017). The index in the information above shows that tourism economy manages activities of persons travelling to and staying in places outside their usual environment or place of domicile to explore tourism products with the corresponding socio-economic impacts on the host communities.

\section{RESEARCH METHODOLOGY}

In the current study, travel and tourism regulatory framework (TTRF) proposed by the world economic forum in collaboration with Deloitte, International Air Transport Association (IATA), and the International Union for Conservation of Nature (IUCN), World Tourism Organization (UNWTO), and the World Travel and Tourism Council (WTTC) in 2013 is adopted to explain sustainable tourism economy in Nigeria. Jennifer \& Thea (2013) highlighted the elements of TTRF to include: Policy rules and regulations, Environmental sustainability, Safety and security, Health and hygiene, and Prioritisation of travel and tourism. Insightful inferences on the relevancies of each of the five broad categories of travel and tourism regulatory framework towards development and sustenance of Nigeria tourism economy were deduced based on other relevant literature as follows.

\section{REGULATORY FRAMEWORK AND THE NIGERIA TOURISM ECONOMY}

The relationship between the five elements of travel and tourism regulatory framework in respect of Nigeria tourism economy are discussed as follows. Tourism Policy, Rules and Regulations and Nigeria Tourism
Economy

This explains the extent to which the policy environment of a country supports tourism business investments (Okoli, 2001; Jennifer \& Thea, 2013; Bello, 2018). In 2006, the Nigerian government developed the Nigeria Tourism Master Plan (TDI, 2014) with sole aim to providing a policy thrust capable of enhancing the Nigeria tourism sector (BGL, 2014). The gazette takes into account the extent to which foreign ownership and foreign direct investment (FDI) in tourism are welcomed and facilitated by the government of Nigeria, how tourism investment rights are protected, and the time and cost required for setting up a tourism business in Nigeria (NTDC, 1997). Other information contained in the gazette include; tourist's visa requirements, and bilateral air service agreements among others. Fifteen years after the master plan had been drawn; the observation on Nigeria's tourism industry is probably worse (BGL, 2014; Bello et al. 2016) due to poor implementation. Years after, the tourism and hospitality industry still represent a meager $(4.8 \%)$ of the Nigeria's GDP in 2016 (Ekwujuru, 2016; Jumia Travel, 2017). The implication of this is that international tourists and tourism investors may likely choose tourism destinations outside Nigeria a preferred tourist destination rather than Nigeria for patronage and investment respectively.

Inference that could be drawn from the above information is that weak tourism policy, rules and regulations including, unwillingness of the relevant agencies of Nigeria government to review and painstakingly implement Nigeria's tourism masterplan will perpetually keeps the sector in backward position on the Africa continent.

\section{Environmental Sustainability and Nigeria Tourism Economy}

Realising the importance of the natural environment for providing an attractive location for tourism and other business development, the government and people of Nigeria had made various efforts towards sustaining her environment for accelerated tourism business development (Atilola, 2012). Various efforts made include, establishment of environmental coordinating bodies, formulation of environmental legislations and regulations, promotion of environmental based strategic policies and plans, and partnerships with the nongovernmental bodies to save the environment (NCP, 1992). Through these various efforts, Nigeria had achieved major milestone in environmental protection and conservation of natural resources (NCP, 1992). However, all these efforts are not yielding positive impacts on attracting tourism investor's confidence to visit and invest in Nigeria eco-tourism subsector. The reason for this may be due to un-competitive 
nature of the Nigeria environmental regulations that makes eco-tourism development practices difficult in the country.

\section{Safety and Security and Nigeria Tourism Economy}

Safety and security are important factors that defines the competitiveness of a country's tourism economy (Bello et al. 2014). Insecurity through crime and terrorism had been identified as one of the major problems confronting the development of tourism economy in Nigeria (Bankole, 2002; Bello et al. 2014). According to 2019 edition of the Global Peace Index (GPI), Nigeria is ranked among the five least peaceful countries in Sub-Saharan Africa (Aworinde, 2019). The GPI measures peacefulness across three domains: safety and security, ongoing conflict, and militarisation. Despite notable military advances, and apparently premature proclamations of Boko Haram's defeat by government forces in Nigeria, the group remained a threat to national security. Abductions, suicide bombings, banditry, and attacks on civilian targets by Boko Haram persisted. Aworinde (2019) reports that at least 1,200 people died and nearly 200,000 were displaced in the northeast in 2018. In June, 2019 at least 84 people were killed in double suicide bomb attacks attributed to Boko Haram at a mosque in Mubi, Adamawa State. The author further opined that decades old communal conflict between nomadic herdsmen and farmers in the Middle Belt intensified in 2020 and further aggravated the security situation in the country. At least 1,600 people were killed and another 300,000 displaced as a result of the violence. In July 13th- $19^{\text {th }}, 2020,47$ deaths and 14 kidnappings occurred due to Boko Haram and Fulani Herdsman- related clashes. In July $20^{\text {th }}$, 2020, President Muhammadu Buhari condemns the killing of 37 innocent people by bandits in the Sokoto State. Also, in July $27^{\text {th }}$, more than 60 dead as Boko Haram target a funeral procession, in retaliation to an alleged incident where villagers fought off an earlier Boko Haram attack in Borno. In July $29^{\text {th }}, 25$ Soldiers and 47 Boko Haram militants were killed during a clash in Kukawa, Borno while in August $2^{\text {nd }}, 5$ pastors were reportedly abducted by the Fulani on their way to attend an annual church conference in Ogun State. All the above-mentioned security cases affirmed failure in Nigeria's security architecture.

The implications of the above analysis are that tourists and tourism investors are likely to be deterred from traveling to or investing in Nigeria due to insecurity. It is also worthwhile to note that the government of Nigeria cannot afford to compromise the safety and security of the tourism entrepreneurs and their investments, if intending to develop her tourism economy. The argument above shows that for a country to be competitive in tourism investment and tourist patronage, the government must take into account the costliness of common crime and violence as well as terrorism, and the extent to which police services can be relied upon to provide protection from crime as well as the incidence of road traffic accidents in the country.
Prioritisation of Travel and Tourism and Nigeria Tourism Economy

The extent to which the government priorities the travel and tourism economy has an important impact on travel and tourism competitiveness of a country (Jennifer \& Thea, 2013). It sends a clear signal of the government's intentions, which can have positive spillover effects such as attracting further private investment into the sector. Prioritisation of the tourism economy can be reflected in a variety of other ways as well, such as government efforts to collect and make available travel and tourism data on a timely basis and commissioning high-quality destination-marketing campaigns. Realising that tourism is a strong alternative to crude oil as a revenue earner; the government of Nigeria in 2006 selected the tourism sector as one of six priority areas central to the revival of the Nigeria economy (BGL, 2014). Tourism became a cardinal stone for achieving the Nigeria's 7-point agenda, its Vision 20:2020 program, and the quest for attracting foreign direct investment (Bello \& Bello, 2012). The authors affirmed that the tourism sector in Nigeria suffered from a policy shift when the reformists, President Olusegun Obasanjo left power in 2007. The tourism industry has fallen off the radar once again and is still straddling for attention while more Nigerians are exporting jobs and revenues to less endowed destinations.

\section{Health and Hygiene and Nigeria Tourism Economy}

Health and Hygiene is the act of creating and maintenance of conditions favourable to good health. Good health and sanitary practices are fundamental for tourism competitiveness of a country (Jennifer \& Thea, 2013; Bello et al. 2014). Access to improved sanitation practices within a country is important for the comfort and health of travelers. In the contemporary Nigeria, it is common to see people selling foods, sleeping, eating and drinking beside human faces in cities across the 36 states of the federation (Bello et al. 2014). From the backyard of an average compound in Nigeria, to public places such as railways, motor parks, airport terminal buildings, filling stations, footpaths, highways, street roads, playing grounds, prayer houses, forests and stadiums, there is faces everywhere. This information validated the global survey that identified Nigeria as the second in the world among countries where open defecation is prevalent (Adedigba, 2019). It is not surprising that open defecation costs Nigeria over US\$ 1 billion yearly (UNICEF, 2019). Open defecation in this context explains condition where human fasces are disposed of in fields, forests, open bodies of water, beaches or other open spaces or disposed with solid waste. Report had it that 47 million Nigerians representing 24.4 per cent of the population practice open defecation (UNICEF, 2019).

Out of the 47 million people, North-Central Nigeria has 53.9 per cent which constitute 15 million people making it the highest region practicing open defecation in the country. South-West has 28 per cent, and South-East has 22.4 per cent. North-East has 21.8 per cent, South-South 17.9 per cent, and 
North-West 10.3 per cent (UNICEF, 2019). Efforts at promoting effective hygiene and health practices in Nigeria have been piecemeal and have not been effective enough to engender the required mass behavioral change. However, Nigeria needs additional two million toilets annually over 7 years for effective sanitary control (UNICEF, 2019). This implies those nearly 20 million household toilets and 43,000 toilets in schools, health centers and public places needed to be constructed. This will be requiring an average annual investment of about NGN 100 billion (UNICEF, 2019a). To this end, Nigeria needs N959 billion to eradicate open defecation by 2028 .

One of the inferences that could be deduced from the above information is that embassy of countries in Nigeria may put Nigeria- bound- tourists in their respect countries on red alert on the possibility of outbreak of epidemics in the country. Thus, advising their nationals not to choose Nigeria as a preferred tourism destination.

\section{CONCLUSION AND RECOMMENDATIONS}

Major conclusions from this study revealed that Nigeria can only maximize her tourism economy potentials if the government put in place the required tourism regulatory framework (TRF). The paper also concludes that environmental sustainability is key to providing an attractive Nigerian tourism business development and competitiveness. It is further concluding that a secure and safe Nigeria is critical to unlocking the competitiveness of the Nigerian tourism economy. The study further revels that the extent to which the government of Nigeria priorities the tourism sector has an important impact on the competitiveness of tourism economy in the country. It is also resolved that good health and sanitary practices are fundamental for Nigeria to unlocking her tourism economy competitiveness.

In the light of the foregoing, the government of Nigeria should vigorously purse favorable policy environment that supports tourism business investment. Therefore, urgent review of the current Nigerian tourism master plan is strongly recommended. Hence, the proposed reviewed tourism master plan should take into account issue of tourism resources stocktaking, tourism product development strategies, and human capital development initiatives in tourism, international tourism marketing, tourism investment right protection, and tourism infrastructure development. Due to the huge financial resources required for this purpose, governments should explore Public-Private-Partnership arrangements under mutually agreed legal frameworks.

Furthermore, realizing the importance of the environmental sustainability in providing an attractive environment for tourism business development, and corresponding with the fact that previous efforts of government in this regard have not yielded the desired positive impacts. This paper therefore sturdily recommends that the government and the people of Nigeria should renew her effort towards sustaining her environment for accelerated tourism business development. In this wise, the National Environmental Policy Guidelines and Standards; Environmental Impact Assessment (EIA) Law; National Energy Policy; and Nuclear Safety and Radiation Protection Legislation should be urgently reviewed in line with the current environmental realities.

In view of the realities that safety and security are critical factors determining the competitiveness of a country's tourism economy, this paper therefore recommends decisive overhauling of the Nigerian security architecture. In this wise, international collaboration is stalwartly recommended. Aside, politicizing the security framework of the country should be strappingly avoided. Quality investment in training and retraining of security personnel including, provision of modern weapons is muscularly recommended. Recruitment and enlistment officers and men of the security agencies on the basis of intellectual capacity and qualification rather than quota system is also recommended.

Appreciating that the extent to which the government of Nigeria priorities the tourism sector has an important impact on the competitiveness of tourism sector in the country. This paper therefore recommends that government of Nigeria should make decisive efforts to collect and make available travel and tourism data on a timely basis. This is expected to help in tourism planning and designing high-quality destination-marketing campaigns. The government of Nigeria should urgently restore tourism to a full ministry status as against the current merger of the sector with the ministry of information, culture and national orientation. A bold step to appoint experts as minister of tourism is strongly recommended.

Finally, recognizing that access to improved sanitation practices is important for the comfort and health of travellers, this paper therefore recommends that a state of emergency be declared in WASH sector. Aside, the government of Nigeria should announce in clear terms the plan by the country to become open defecation free country by year 2025 .

\section{REFERENCES}

[1] Adedigba, A. (2019). Nigeria worst African country in open defecation, second globally. Retrieved from Premium Times, Sunday, $\quad$ October 6, 2019: https://www.premiumtimesng.com/news/top-news/337023nigeria-worst-african-country-in-open-defecation-secondglobally-report.html.

[2] Anthony, B., Marcelo, F., Andrew, H., Sarah, J., Neil, K., David, P., Kelvin, V. C.;. (2004). Vission 2020; Forcasting International Student Mpbility; A UK Perspective. England: British Council Department.

[3] Atilola, O. (2012). Climate Change and the Environment: Issues and Geo-information Challenges. Working Week 2012: Knowing to Manage the Territory, Protect the Human Environment and Evaluate the Cultural Heritage. Rome, Italy, 6-10 May.

[4] Aworinde, T. (2019). Nigeria Ranks 148 on Global peace Index. Retrieved from Punch Newspaper June 16th: https://punchng.com/nigeria-ranks-148th-on-global-peace-index.

[5] Bankole, A. S. (2002). Services Trade Policy and the Nigerian Tourism Sector:A Note of Tourism Contribution, Constraints and Opportunities. A Paper Submitted to the African Journal of 
Economic Policy. Ibadan: Department of Economics; University of Ibadan.

[6] Bello, Y. O and Majebi, E. C. (2018). Religion Tourism and Social Development. Journal of Faculty of Management Sciences, 192-210.

[7] Bello, Y. O. (2018). Hospitlaity and Tourism Economics. Ondo: Grace Excellent Publishers.

[8] Bello, Y. O., and Bello, M. B. (2015). Lodging Service Management and Administration, Theory and Practice. Benin: Diamond Publishing House.

[9] Bello, Y. O., and Majebi, E. C. (2018). Lodging Quality Index Approach: Exploring the Relationship Between Service Quality and Customers Satisfaction in Hotel Industry. Journal of Tourism and Heritage Studies, 7, (1), 58-78.

[10] Bello, Y. O., Bello, M. B., \& Raja, N. R.Y. (2014). Travel and Tourism Business Confidence Index in Nigeria: Issues and Challenges . African Journal of Hospitality, Tourism and Leisure , 3, (2), 1-15.

[11] Bello, Y. O., Bello, M. B., and Obiora, N. J. (2017). Sport Tourism: Perceived Economic Impact of Okpekpe Marathon Race on the Host Community . Journal of Tourism and Heritage Studies , 6, (1), 113-132.

[12] Bello, Y. O., Udi, I. O., Bello, M. B., and Raja, N. R. Y. (2016). Introduction to Hospitality management. Ondo: Grace Excellent Publishers.

[13] Bello, Y.O., and Bello, M. B. (2017). Hotel Front Office Management; The Contemporary Approach . Ondo: Grace Excellent Publishers.

[14] Bello, Y.O., and Bello, M.B . (2012). Infrastructure Development: A Strategic Approach for Sustainable Hospitality Business in Edo State . Continental Journal of Sustainable Development, 3, (1), 47-54.

[15] Bello, Y.O., and Bello, M.B. (2017). Exploring the Relationship between Religion Tourism and Economic Development of a Host Community . International Journal of Business and Management Invention, 6, (9), 41-51.

[16] BGL Group. (2014). Economic Note: Nigeria Tourism Industry: A Revolutionized Tourism Sector as a Panacea for a Thriving Hospitality Business. Retrieved January 26, 2014, from www.research.bg/group.com.

[17] Ekwujuru, P. (2016). Tourism contributes N1.7bn to GDP in Q3 2016. Lagos: Vangard Newspaper, Sunday 19 November.
[18] Jennifer, B., \& Thea, C. (2013). Travel and Tourism Competitiveness Report: Reducing Barriers to Economic Growth and Job Creation. Geneva: World Economic Forum.

[19] Jumia Travel. (2017). The Hospitality and Tourism Outlook in Nigeria. Lagos: Jumia Travel Nigeria.

[20] Naido, V. (2007). Research on the Flow of International students to UK Universities: Determinants and Implications. Journal of Research in International Education, 6, (3) 287-307.

[21] Nigeria Country Profile. (1992). Implementation of Agenda 21: Review of Progress made since the United Nation Conference on Environment and Development. Retrieved from www.un.org/esa/earthsummit/nigeriac.

[22] Nigerian Tourism Development Corporation. (1997). Official Gazette No. 21 vol. 84 of 9th April 1997 of NTDC. Abuja: Nigerian Tourism Development Corporation.

[23] Okoli, C. I. (2001). Tourism Development and Management in Nigeria. Enugu: Jee Communication.

[24] Roberts, A., Chou, P., and Ching, A. (2010). Contemporary Trend in East Asia Higher Education: Disposition of International Students in Taiwan Universities. Higher Education, $59,149-166$.

[25] TDI. (2014). Nigeria Tourism Development Master Plan . Retrieved from www.tourismdev.com/nigeria_tourism_devel opement_master_plan. Retrieved on, 26.01.14.

[26] UNICEF. (2019). Nigeria worst African country in open defecation, second globally. Retrieved from Premium Times, Sunday, October $\quad 6, \quad 2019$ : https://www.premiumtimesng.com/news/top-news/337023nigeria-worst-african-country-in-open-defecation-secondglobally-report.html.

[27] UNICEF. (2019a). Nigeria needs additional two million toilets annually over 7 years. Retrieved from https://www.premiumtimesng.com/news/more-news/331249sanitation-nigeria-needs-additional-two-million-toilets-annuallyover-7-years-unicef.html.

[28] United World Tourism Organisation. (2018). World Tourism barometers. Madrid Spain: UNWTO.

[29] Wall, G., and Mathiesom, A. (2006). Tourism: Change, Impacts and Opportunities. New York: Pearson Prentice Hall.

[30] World Tourism Organization. (2016). UNWTO World Tourism Barometer. Retrieved from Madrid: UNWTO:http://www.unwto.org/facts/eng/barometer.htm. 